\title{
Stability of Money Demand Function in Nepal
}

\author{
Siddha Raj Bhatta \\ Assistant Director, Nepal Rastra Bank, Kathmandu, Nepal \\ E-mail: siddhabhatta@gmail.com
}

\begin{abstract}
This paper examines the long-run stability issue of money demand function in Nepal using the annual data set of 1975-2009 by using the recently developed ARDL modeling to cointegration popularized by Pesaran and Shin (1999). The bounds test shows that there exists the long-run cointegrating relationship among demand for real money balances, real GDP, and interest rate in case of both narrow and broad monetary aggregates. Further, the CUSUM and CUSUMSQ test reveal that both the long-run narrow and broad money demand functions are stable. The results show that demand for money balance in Nepal is a stable and predictable function of a few variables and the central bank can rely on the monetary aggregates as intermediate targets for achieving the broad economic objectives.
\end{abstract}

Keywords: money demand function, cointegration, error correction modeling

JEL Classification Code: E, E4, E41

\section{INTRODUCTION}

The demand for money is one of the key functions in all monetary policy models of the economy. A sound monetary policy formulation presupposes theoretically coherent and empirically robust model of money demand. The stability of money demand function is crucial for the effectiveness of monetary policy in offsetting the fluctuations that may arise from the real sector of the economy. Given the importance attached to money demand in the success or failure of an activist monetary policy, it is not surprising that the demand for money is one of the most controversial and heavily researched areas in macroeconomics (Bose and Rahman, 1996).

A good understanding of the determinants of the demand for real money balances in the economy by investigating the behavior of the money demand function is crucial for the formulation and implementation of an effective monetary policy. Moreover, the identification of a stable relationship between the demand for money and its determinants provides empirical evidence that the monetary targeting is an appropriate framework for economic stabilization policy (Rutayisire, 2010). That is, if the demand for real balances has a consistent or stable relationship with its determinants, the changes in money stock has predictable effects on income and output and the required change in the money stock to restore the equilibrium in the economy can be easily worked out. This is what is needed for the stability of the economy. In such a case, the central bank can bring the desired changes in the economy by using monetary aggregate as a target variable. Thus, if the central bank relies on control of monetary aggregates as its policy instruments, it must 
believe in a known and reliable connection between changes in that aggregate and changes in the arguments of the money demand function in order for its policy to have predictable effects on those arguments. If instead the central bank relies on interest rates as targets and adjusts the monetary aggregate through daily reserve management to whatever level is required to hit them, instability of the demand for money could make the required reserve changes both large and unpredictable. In such a case, disorderly financial markets might well result (Cameron 1979).

For any central bank, stability issue of the money demand function is one of the most important guiding policy issues that helps decide whether to use the monetary targeting strategy or inflation targeting strategy in the monetary policy in bringing the desired changes in the economy. This issue has been triggered further by the abandonment of monetary targeting strategy by many developed countries such as Canada, Newzeland, Brazil, Turkey, Norway, Australia, etc as they switched to inflation targeting strategy arguing that the demand for money function is tending to become unstable. Stability of the demand for money function is, therefore, the focal point for any central bank's policy. In this context, an assessment of the monetary policy of Nepal requires first to test the stability of money demand function. The central bank of Nepal has been using money stock as the intermediate target of the monetary policy. Especially after the adoption of financial liberalization in the 1980s, as argued by Khan and Wadud (2003), there might have been the forces that might have caused the instability in money demand function and rendered the monetary policy ineffective. In such a case, the stability issue of the money demand function needs an intense focus for justifying the working of the monetary targeting strategy.

The main objective of this paper is to examine whether there is any significant longrun equilibrium relationship among real money balances, the scale variable (real GDP), and the opportunity cost variable (interest rate) in Nepal and to examine the long-run stability issue of the money demand function.

The rest of the paper is structured as follows. Section 2 presents the review of some studies at international and national level and justifies the need of the study, section 3 presents the methodology and discusses the data sources, section 4 synthesizes the estimation results, and the last section presents the concluding remarks.

\section{LITERATURE REVIEW}

In literature, money demand function has been studied using both 'velocity' and 'conventional' formulation approaches. In comparison to the relatively limited literature on the velocity approach, 'conventional' money demand function has attracted a large number of researchers, primarily because it is easy to understand the formulation (Omer, 2010). Even if one starts with the Post Bretton Woods Period, Goldfeld (1973), Boughton (1981), Arango and Nadiri (1981), Butter and Fase (1981), Mehra (1991), etc are a few among the vast pool of the authors who made a significant contribution in this field of banking on the conventional models. A recent technique is the cointegration analysis and use of error correction modeling to time series modeling used in the money demand function. The 
following section presents a review of the empirical studies on the money demand function at national and international level.

\subsection{Review of International Empirical Studies}

Taylor (1993) has estimated the short-run and long-run demand for broad money for United Kingdom using high quality data from 1871-1913 applying recent econometric technique of Johansen's Maximum Likelihood approach to cointegration and has discovered a unique, statistically significant long-run money demand function relating broad money, prices, real income and the long-term interest rate. This study displays price and income homogeneity and a plausible long-run interest rate semi-elasticity. This short-run demand function was found to be superior to previous estimates for this period on statistical grounds. It fitted well with well-determined coefficients and shows no sign of structural instability.

Lumas and Mehra (1976) have analyzed the stability of demand for money in US with the sample annual data of 1900 to 1974 using the varying parameter approach developed by Cooley and Prescott (1973). They found that the demand for money equations which regress money (M1 or M2) on income and interest rates but omit a lagged value of the dependent variable are not stable.

Hamori and Hamori (1999) have found the demand for money in Germany unstable. They sample used is 1969:Q1 to 1996:Q3. The included variables are real GDP, M1, M2, M3, and call rates. They have used chow test to test the stability of the money demand function.

Bahmani-Oskooee (2001) has tested the stability of money demand in Japan using ARDL modeling to cointegration analysis by using the sample data 1964:Q1 to 1996:Q4 and found that demand for broad money is stable. The included variables are M2, real income, and interest rate. With the help of CUSUM and CUSUMSQ test, he has found a stable relationship in the money demand function.

Bahmani-Oskooee and Chi Wing $\mathrm{Ng}$ (2002) have examined the long-run demand for money in Hong Kong using the ARDL cointegration procedure using the sample data 1985:Q1 to 1999:Q4. They have concluded that M2 is cointegrated with its determinants real income, domestic interest rate, foreign interest rate, and foreign exchange rate and all the coefficients have been found to be significant. They have used the CUSUM and CUSUMSQ test to confirm the stability of the money demand function and found it stable. Their study has suggested that in addition to the conventional scale and domestic interest rate variable, the foreign sector consideration do matter in explaining the variation in the broad money aggregate for a highly open economy like Hong Kong. The coefficient of exchange rate has been found to be positive supporting the result that currency depreciation would reduce the demand for domestic currency.

Bahmani-Oskooee and Rehman (2005) have also used the ARDL modeling for a number of countries like Singapore, Malaysia, India, Indonesia, Pakistan, Philippines, and Thailand. The sample period used is 1972:Q1 to 2000:Q4. The included variables are real M1, real M2, real GDP, inflation rate, and exchange rate. 
Their study has shown that demand for M1 is stable in India, Indonesia, and Singapore while in other countries M2 is stable.

Halicioglu and Ugur (2005) have empirically analyzed the narrow money demand function in Turkey over the period 1950 to 2002. The variables included are real narrow money stock per capita, real national income per capita, interest rate on alternative assets, and nominal exchange rate. The study has shown that there is a long-run relationship between the narrow money aggregate (M1) and its determinants: national income, interest rate, and exchange rates. The methodology used is the single equation cointegration technique, ARDL as proposed by Pesaran et al. (2001). The CUSUM and CUSUMSQ stability tests indicate that there exists a stable money demand function implying that narrow money aggregate can be used as an intermediate target variable of monetary policy in Turkey.

Akinlo (2006) has used the ARDL modeling to test the stability of the demand for money in Nigeria by using the sample data from 1970:Q1 to 2002:Q4 and found that the variables M2, real GDP, nominal exchange rate, and interest rate are cointegrated. The CUSUM and CUSUMSQ tests reveal that a stable relationship exists between the variables.

Bahmani-Oskooee and Bahmani (2007) have examined the money demand function for broad money balances in Iran in the post revolutionary period of Islamic Revolution 1979 considering the data set from 1979 to 2007. They have used the ARDL modeling approach to cointegration analysis including the variables: real GDP, inflation, exchange rate, and a volatility measure of the real exchange rate. Their examination has concluded that the variables included in the money demand function are strongly cointegrated. Their conclusion is that the M2 money demand function of Iran in the study period is stable as such the revolution has not led to the parameter instability of the money demand function. Their study has argued that in addition to Mundell's theory on exchange rate being an important determinant of the demand for money, exchange rate volatility also serves as another important variable that impacts demand for money and should therefore be included in the money demand function. Further, the study has revealed that indeed, exchange rate volatility has both short-run as well as long-run effects on the demand for real M2 monetary aggregate in Iran during the post revolutionary period of 1979 to 2007 , and is therefore a very important determinant of demand for money.

Ahmed and Islam (2007) have empirically explored the long-run equilibrium money demand relationship as well as the short-run dynamics in the context of Bangladesh for M0, M1, and M2 using the Johansen and Julius multivariate cointegration analysis using the quarterly data from 1990 to 2006. This study has revealed that there exists a statistically significant long-run equilibrium relationship among real money balances of various types, real income and respective nominal interest rates. The demand for real balances in the economy is strongly dominated by the transaction motive for holding money as shown by the elasticity of real income. 
Bahmani-Oskooee and Wang (2007) have studied the stability issue in Chinese money demand function with ARDL modeling to cointegration and found that in China, M1 money demand function is stable while M2 money demand function is not during the study period 1983:Q1 to 2002:Q2. The included variables are real income, domestic interest rate, foreign exchange rate, and the nominal effective exchange rate. They have recommended that Chinese central bank should use M1 monetary aggregate rather than M2 in implementing monetary policy.

Samreth (2008) has also used the ARDL modeling to cointegration analysis in Cambodia with the monthly data from 1994:12 to 2006:12. His study has found that there exists cointegration among the variables included in the money demand function which are real income, inflation, exchange rate, and real narrow money balances (M1). The coefficient of exchange rate is negative supporting the currency substitution phenomenon in Cambodia. The estimated results have further shown that the political turmoil in Cambodia has no impact on money demand function. The CUSUM and CUSUMSQ tests reveal that estimated model is roughly stable.

Ashsani (2010) has compared the estimation results from vector error correction modeling (VECM) and ARDL modeling to cointegration analysis to money demand in Indonesia. The results suggest that there was a cointegrating relationship among real broad money aggregate (M2), real income, and interest rate in Indonesia during the study period. The ARDL modeling was found better than VECM in terms of stability of the model, significant error correction term, and other indicators like R-square and R-bar square. The ARDL model was stable while VECM was not stable. The study has covered the sample period from 1990:Q1 to 2008:Q3.

Omer (2010) by using the ARDL Model has found that in Pakistan the velocities of M0 (reserve money) and M2 are independent of interest rate and depend on income and business cycle fluctuations where as velocity of M1 significantly depends on interest rate. This implies that M0 and M2 (broad money) can be used as nominal anchors for operational and the intermediate targets, respectively. He has also found that there exists a stable and long-run relationship between money velocities and its determinants such as, per capita real permanent income, and transitory income. His Study has covered the annual data from 1975 to 2006.

\subsection{Review of National Empirical Studies}

Empirical studies at the national level using the latest techniques of cointegration and error correction modeling are still lacking. The main problem behind this is the lack of sufficient data observations, lack of high frequency data, etc. Some of the studies relating to money demand function and test of its stability in Nepalese context are as follows:

Poudel (1987) has estimated the money demand function of Nepal using the OLS regression with the data sample $1974 / 75$ to $1986 / 87$. He has concluded that the demand for narrow money in Nepal is highly stable. Also, aggregate real income is highly statistically significant determinant of the demand for all types of money defined in real terms. The income elasticity of the demand for $\mathrm{M} 1$ is greater than unity lying in the range of 2.31 to 2.47 implying that money is a luxurious 
commodity. The nominal rate of interest is not the appropriate rate in explaining the demand for real money balances in Nepal but the real rate of interest turns out to be a significant variable. He has also concluded that McKinnon hypothesis fits well in Nepal. However, this study has not tested the stability of the money demand function.

Khatiwada (1997) has analyzed the money demand function in Nepal using the annual data from $1975 / 76$ to $1995 / 96$. He has concluded that demand for real money balance in Nepal is a stable and predictable function of a few variables (real income and interest rate). He has concluded that the financial reforms have not significantly affected the money demand function.

Pandey (1998) by using an error correction dynamic specification found that demand for narrow money (M1) is highly stable and this has been confirmed by all the statistical tests that were employed. He also has found that the rate of interest on savings deposits does not have a significant effect on the demand for M1 balances. This study has also established the fact that money is a luxurious item for the Nepalese people and the expected rate of inflation does not seem to have a significant influence on the demand for M1 in Nepal. However, he has not tested the stability of the demand for broad money.

Gaudel (2003) has used Chow Test to investigate the stability for the three alternative definitions of money in the demand function using OLS estimation and found that a stable relationship is maintained in all definitions of money. His study has covered the data set from 1965 to 1994 only. He has found that the demand for money in Nepal over the sample period is best explained as a function of income as a scale variable and rate of inflation and interest bearing assets as opportunity cost variables. From the result of the chow test, it is found that a stable relationship is maintained in all the three definitions of money. The overall results of the linear models conclude that narrow definition of money is superior to broad definition of money.

The studies at international level reviewed in Section (2.1) imply that most of the studies in the money demand function in the international level have used cointegration analysis. It is because the results from OLS estimation can suffer from spurious regression phenomenon if the data are non-stationary. When the standard assumption of stationarity breaks down, straightforward application of regression technique no more remains valid. It therefore becomes necessary to look for the presence of unit roots, prevalence of cointegration and consequent application of error correction models (ECMs). Further, they give support to the use of ARDL modeling over other methods like Johansen multivariate cointegration technique, Phillips and Hansen technique, etc in case of annual data and/or small number of observation. It is because the validity of the result may be questioned in case of small size of sample in latter methods. They also reveal the fact that the real GDP, interest rate, inflation, and exchange rate are the most common determinants of money demand. The national literature on the money demand function makes few things clear: first, there has been a considerable lapse of time in the empirical study of money demand function since Khatiwada (1997) and Pandey (1998); secondly, 
the available literatures are based on OLS method of estimation except Pandey (1998) which utilizes Engle-Granger Cointegration Method. These studies prompt one to apply the recently developed cointegration technique to the formulation of money demand function to avoid the phenomenon of spurious correlation and spurious regression. Therefore, there has arisen the need to re-estimate the money demand function extending the data set beyond 1997 and examine the stability issue. This study, thus, aims to overcome these two shortcomings by extending the data set from 1975 to 2009 and by adopting the ARDL modeling to cointegration analysis proposed by Pesaran and Shin (1999) to get rid of the spurious regression problem.

\section{DATA AND METHODOLOGY}

\subsection{The General Model}

In the literature of money demand function, the basic model of money demand begins with the following relationship:

$M / P=f(S, O C)$

Where, the demand for real balances $M / P$ is a function of the chosen scale variable(s) to represent the economic activity and the opportunity cost of holding money (OC). M stands for the selected monetary aggregates in nominal term and $\mathrm{P}$ for the price (Sriram, 2000).

\subsection{Selection of Variables \\ Scale Variable}

There is a wide controversy among researchers on the selection of appropriate scale variable. Studies in the developed countries have mostly used wealth and permanent income as scale variables. The studies in US have been mostly specified in terms of permanent income as the scale variable [Brunner and Meltzer (1964), Chow (1966), Laidler (1966), Khan (1974)] while there are some emphasizing the use of wealth as a scale variable [Meltzer(1963), Hamberger (1966)] and some have used the measured income [Goldfeld (1973), Arango and Nadiri (1981)]. However, in the context of developing countries, measured income has been used in most empirical studies. Several studies in India [Gujarati (1968), Bhattacharya (1974), Sampath \& Husain (1981)] have used current income as the scale variable. The reason for this may be two-fold: first, the information on wealth is not available in the non-monetized economy; and second, permanent income series cannot be meaningfully constructed because of very short time series national income data. In the context of Nepal, several studies [Poudel (1989), Khatiwada (1997), Pandey (1998), Gaudel (2003)] have used real GDP as the scale variable and found significant and stable relationship between real GDP and the stock of money holding. Thus, following the literature, this study has selected real GDP as the scale variable.

\section{Opportunity Cost Variable}

Selection of opportunity cost variable also is not free of debate. There is the ongoing controversy as which interest rate is the best indicator of the opportunity cost of holding money. Some argue that the long-term bond rate is better choice as 
it is more representative of the average rate of return on capital. The Keynesian theory also supports the long-term interest rate as it is the interest rate that is linked with investment decision and hence the level of income. Since the economic theory on the money demand function does not provide any clear cut guideline on the choice of interest rate, researchers have tried different interest rates in modeling the money demand function.

In case of US, Khan (1974) and Jacobs (1974) have used the long-term rate of interest whereas Heller (1965) and Laidler (1971) have used short-term interest rate. In case of India, Gupta (1970) and Bhattacharya (1974) have used the shortterm interest variable in the money demand function. In the context of Nepal, the use of T-bill rate or long-term bond rate is irrelevant as these instruments are not a significant part of asset portfolios. Further data are not available for long-term fixed deposit rate for the whole study period. Thus, in this study, rate of interest on saving deposit has been used as a proxy to interest rate on short-term financial assets to model the narrow money demand and the interest rate on one-year fixed deposit has been used as a proxy for long-term interest rate to model the broad money demand function.

\subsection{The Empirical Model}

In this study, following Bahmani-Oskooee (2001), the following model has been considered.

$\ln m_{t}=a+b \ln y_{t}+c r_{t}+e_{t}$

Where, $m_{t}$ is a monetary aggregate in real term, $y$ the real GDP, $r$ the interest rate and $\mathrm{e}$ is a white noise error term. Based on the conventional economic theory, the income elasticity parameter, $b$, is expected to be positive whereas the interest elasticity parameter, $r$, is expected to be negative.

To model the money demand functions for both narrow and broad money aggregates, equation (1) can be written in the form of two different models: Model I for Narrow Money Demand Function and Model II for Broad Money Demand Function.

Model I (Narrow Money Aggregate): $\quad \ln m_{1 t}=\mathrm{a}+\mathrm{b} \ln y_{t}+\mathrm{c} r_{s d t}+\mathrm{e}_{\mathrm{t}}$

Model II (Broad Money Aggregate): $\quad \ln m_{2 t}=\mathrm{a}+\mathrm{b} \ln y_{t}+\mathrm{cr} r_{f d t}+\mathrm{e}_{\mathrm{t}}$

The details of all the variables used in the formulation of equations (2), (3) and other variables used in this study have been presented in Table (1). 
Table 1: Variable Details

\begin{tabular}{|c|c|}
\hline $\begin{array}{l}\text { Variables } \\
\text { Name }\end{array}$ & Details \\
\hline $\mathrm{m}_{1 \mathrm{t}}$ & $\begin{array}{l}\text { Real Narrow Money Stock defined by the narrow money stock } \\
\text { divided by CPI (FY 2000/01=100) }\end{array}$ \\
\hline$m_{2 t}$ & $\begin{array}{l}\text { Real Broad money stock defined by the broad money stock } \\
\text { divided by CPI (FY 2000/01=100) }\end{array}$ \\
\hline$y_{t}$ & $\begin{array}{l}\text { Real GDP defined by nominal GDP deflated by the implicit GDP } \\
\text { deflator (FY } 2000 / 01=100)\end{array}$ \\
\hline $\ln \mathrm{m}_{1 \mathrm{t}}$ & Natural logarithm of real narrow money stock \\
\hline In $m_{2 t}$ & Natural logarithm of real broad money stock \\
\hline $\ln y_{t}$ & Natural logarithm of real GDP \\
\hline$r_{\text {sdt }}$ & Rate of interest on saving deposit \\
\hline$r_{\mathrm{fdt}}$ & Rate of interest on one-year fixed deposit \\
\hline $\begin{array}{l}\text { Narrow money } \\
\text { stock }\left(M_{1}\right)\end{array}$ & $\begin{array}{l}\text { Currency held by public plus demand deposits of the commercial } \\
\text { banks (CC+DD) }\end{array}$ \\
\hline $\begin{array}{l}\text { Broad money } \\
\text { stock }\left(M_{2}\right)\end{array}$ & Narrow money stock plus time deposits (CC+DD+TD) \\
\hline CPI & Consumer price index (FY 2000/01=100) \\
\hline INF & $\begin{array}{l}\text { Expected rate of inflation proxied by the actual rate of inflation } \\
\text { defined by }\left(\mathrm{CPI}_{t}-\mathrm{CPI}_{\mathrm{t}-1}\right) / \mathrm{CPI}_{\mathrm{t}-1}\end{array}$ \\
\hline $\mathrm{rr}_{\text {sdt }}$ & $\begin{array}{l}\text { Real rate of interest on saving deposit defined as nominal } \\
\text { interest rate on saving deposit minus expected rate of inflation }\end{array}$ \\
\hline $\mathrm{rr}_{\mathrm{fdt}}$ & $\begin{array}{l}\text { Real rate of interest on one-year fixed deposit defined as } \\
\text { nominal interest rate on such deposit minus expected rate of } \\
\text { inflation }\end{array}$ \\
\hline
\end{tabular}

\subsection{Estimation Methodology}

There are various techniques for conducting the cointegration analysis on money demand function. The popular approaches are: the well-known residual-based approach proposed by Engle and Granger (1987) and the maximum likelihood approach proposed by Johansen and Julius (1990) and Johansen (1988). When there are more than two I(1) variables in the system, the maximum likelihood approach of Johansen and Julius has the advantage over residual-based approach of Engle and Granger; however, both of the approaches require that the variables have the same order of integration. This requirement often causes difficulty to the researchers when the system contains the variables with different orders of integration. To overcome this problem, Pesaran et al. (1996; 2001) proposed a new approach known as Autoregressive Distributed Lag modeling (ARDL) to cointegration which does not require the classification of variables into $\mathrm{I}(0)$ or $\mathrm{I}(1)$. Therefore, adopting the ARDL approach for cointegration test, there is no need to conduct the unit root test, which is prerequisite for residual-based and maximum likelihood based approaches. Due to these advantages, ARDL approach has gained popularity over recent years and its adoption for empirical analysis on money demand can be found in many published works. Among the prominent works using the ARDL modeling to cointegration are: Bahmani-Oskooee (2001) for Japan, 
Bahmani-Oskooee and Chi wing $\mathrm{Ng}$ (2002) for Hongkong, Bahmani-Oskooee and Rehman (2005) for a number of countries like Singapore, Malaysia, India, Indonesia, Pakistan, Philippines, Halicioglu ang Ugur (2005) for Turkey, Akinlo (2006) for Nigeria, Bahmani-Oskooee ang Bahmani (2007) for Iran, BahmaniOskooee and Wang (2007) for China, Samreth (2008) for Cambodia, Ashsani (2010) for Indonesia, and Omer (2010) for Pakistan.

\subsection{Autoregressive Distributed Lag Model (ARDL) to Cointegration Analysis}

The ARDL bounds testing approach to cointegration was developed by Pesaran and Shin (1999) and Pesaran et al. (2001). Due to the low power and other problems associated with other methods for cointegration test, the ARDL approach to cointegration has become popular in recent years. The ARDL cointegration approach has numerous advantages in comparison to other cointegration methods such as Engle and Granger (1987), Johansen (1988), and Johansen and Julius (1990) procedures: (i) it can be applied on a time series data irrespective of whether the variables are I(0) or I(1) (Pesaran and Pesaran, 1997), while Johansen cointegration techniques require that all the variables in the system be of equal order of integration, (ii) it takes sufficient numbers of lags to capture the data generating process in a general-to-specific modeling framework (Laurenceson and Chai, 2003), (iii) while the Johansen cointegration techniques require large data samples for validity, the ARDL procedure is statistically more significant approach to determine the cointegration relation in small samples, (iv) A dynamic Error Correction Model (ECM) can be derived from ARDL through a simple linear transformation (Banerjee et.al., 1993). The ECM integrates the short-run dynamics with the long-run equilibrium without losing long-run information, (v) The ARDL procedure allows that the variables may have different optimal lags, while it is impossible with conventional cointegration procedures, (vi) The ARDL technique generally provides unbiased estimates of the long-run model and validates the tstatistics even when some of the regressor are endogenous, and (vii) The ARDL procedure employs only a single reduced form equation, while the conventional cointegration procedures estimate the long-run relationships within a context of system of equations.

Following the ARDL approach proposed by Pesaran and Shin (1999), the existence of long-run relationship could be tested using equation (4) below:

$$
\begin{aligned}
\Delta \ln m_{t}=a_{0}+ & \sum_{j=1}^{p} b_{j} \Delta \ln m_{t-j}+\sum_{j=0}^{q} c_{j} \Delta \ln y_{t-j} \\
& +\sum_{j=0}^{r} d_{j} \Delta r_{t-j}+\gamma_{1} \ln m_{t-1}+\gamma_{2} \ln y_{t-1}+\gamma_{3} \ln r_{t-1+\xi_{t}}
\end{aligned}
$$

Where, $m_{t}$ represents real narrow money balances for narrow money demand model (model I) and real broad money balances for broad money demand model(model II), $r$ represents interest rate on saving deposit for model I and interest rate on one-year fixed deposit for model II, similarly, $y_{1}, \gamma_{2}$ and $y_{3}$ are the 
long-run coefficients while, $b_{j}, c_{j}, d_{j}$ and $\zeta_{t}$ represents the short-run dynamics and random disturbance term respectively.

\subsection{Hypothesis}

To test whether the long-run equilibrium relationship exists between demand for real money balances, real GDP, and interest rate, Bounds test (F-version) for cointegration is carried out as proposed by Pesaran and Shin (1999). To test the long-run level relationship between the variables, the hypotheses are:

Null Hypothesis: $\gamma_{1}=\gamma_{2}=\gamma_{3}=0$, that is, the long-run relationship does not exist.

Alternative hypothesis: $\gamma_{1} \neq \gamma_{2} \neq \gamma_{3} \neq 0$, that is, the long-run relationship exists.

These hypotheses are tested by means of the familiar $\mathrm{F}$ statistic. The distribution of this F-statistics is non-standard irrespective of whether the variables in the system are $\mathrm{I}(0)$ or $\mathrm{I}(1)$. The critical values of the F-statistics in this test are available in Pesaran and Pesaran (1997) and Pesaran et al. (2001). They provide two sets of critical values in which one set is computed with the assumption that all the variables in the ARDL model are I(1), and another with the assumption that they are $\mathrm{I}(0)$. For each application, the two sets provide the bands covering all the possible classifications of the variables into $\mathrm{I}(0)$ or $\mathrm{I}(1)$, or even fractionally integrated ones. If the computed F-statistics is higher than the appropriate upper bound of the critical value, the null hypothesis of no cointegration is rejected; if it is below the appropriate lower bound, the null hypothesis cannot be rejected, and if it lies within the lower and upper bounds, the result is inconclusive (Samreth, 2008).

Next step is the estimation of the long-run relationship based on the appropriate lag selection criterion such as adjusted $\mathrm{R}^{2}$, Schwarz Bayesian Criterion (SBC), Akaike Information Criterion (AIC) and Haann Quinn (HQ) Criterion. Based on the long-run coefficients, the estimation of dynamic error correction will be carried out using formulation of equation (5). The coefficients $\delta_{1 i}, \delta_{2 i}$ and $\delta_{3 i}$ show the short-run dynamics of the model and $\delta_{4}$ indicates the divergence/convergence towards the long-run equilibrium. A positive coefficient indicates a divergence, while a negative coefficient indicates convergence. The term ECM is derived as the error term from the corresponding long-run model whose coefficients are obtained by normalizing the equation on $\mathrm{m}_{1 \mathrm{t}}$ and $\mathrm{m}_{2 \mathrm{t}}$ respectively for both money demand models.

$\Delta \ln m_{t}=\delta_{0}+\sum_{j=1}^{p} \delta_{1 j} \Delta \ln m_{t-j}+\sum_{j=0}^{q} \delta_{2 j} \Delta \ln y_{t-j}+\sum_{j=0}^{r} \delta_{3 j} \Delta r_{t-j}+\delta_{4} E C M_{t-1}+v_{t}$

For the test of stability, CUSUM and CUSUMSQ tests as proposed by the Brown et al. (1975) are carried out in this study. Besides these tests, a battery of other tests are also carried out, such as Lagrange Multiplier (LM) test for serial correlation, Ramsey Reset test for functional form misspecification, Jarque-Berra test for normality and KB test for heteroscedasticity. 


\subsection{Econometric Tools Cointegration}

The regression analysis on time series has been much benefited from the concept of cointegration by Granger (1981) and Engle and Granger (1987). They showed that using OLS in case of I(1) variables could be misleading because a nonstationary series violates the basic assumptions of OLS and as such one cannot get the best linear unbiased estimators (BLUE) and also there may exist the spurious or non-sense correlation between non-stationary variables. In the case where the variables are non-stationary at levels but are difference stationary, cointegration methodology allows researchers to test for the presence of long-run equilibrium relationships between economic variables. If the separate economic time series are stationary after differencing or they are integrated of order one, but a linear combination of their levels is stationary, then the series are said to be cointegrated. In other words, two or more $\mathrm{I}(\mathrm{I})$ time series are said to be cointegrated if some linear combination of them is stationary. Formally, given $x_{t}$ and $y_{t}$ are integrated of order one $[\mathrm{I}(1)]$ or are difference stationary processes, they are said to be cointegrated if there exists a parameter $\alpha$ such that $\mathrm{u}_{\mathrm{t}}=\mathrm{y}_{\mathrm{t}}-\alpha \mathrm{x}_{\mathrm{t}}$ is a stationary process or is integrated of order zero $[\mathrm{I}(0)]$.

\subsection{Error Correction Modeling}

Even if $Y_{t}$ and $X_{t}$ variables are cointegrated, that is, there is a long-run equilibrium relationship between them, there may be disequilibrium in the short-run. Thus the error term $u_{t}=Y_{t}-\beta_{1}-\beta_{2} X_{t}$ in the regression equation $Y_{t}=\beta_{1}+\beta_{2} X_{t}+u_{t}$ is called the equilibrium error. This error term can be used to tie the short-run behavior of $Y$ to its long-run value. The Error correction Models (ECM) first used by Sargan and later popularized by Engle and Granger corrects for disequilibrium. The Granger Representation Theorem says that if two variables $Y_{t}$ and $X_{t}$ are cointegrated, then the relationship between the two can be expressed as Error Correction Modeling as:

$\Delta Y_{t}=\alpha_{0}+\alpha_{1} \Delta X_{t}+\alpha u_{t-1}+\epsilon_{t}$

Where,

$\Delta=$ first difference operator,

$\varepsilon_{\mathrm{t}}=$ a white noise error term,

$\mathrm{u}_{\mathrm{t}-1}=$ one period lagged value of the error term from the cointegrating regression

$\left(\mathrm{u}_{\mathrm{t}-1}=\mathrm{Y}_{\mathrm{t}-1}-\beta_{1}-\beta_{2} \mathrm{X}_{\mathrm{t}-1}\right)$

The ECM in equation (6) states that $\Delta \mathrm{Y}_{\mathrm{t}}$ depends on $\Delta \mathrm{X}_{\mathrm{t}}$ and on the equilibrium error term. If the error term is non-zero, the model is out of equilibrium. Here the value of $\alpha_{2}$ decides how quickly the equilibrium is restored.

\subsection{The Data}

This study is based on the secondary data. The data sources are Quarterly Economic Bulletin published by Nepal Rastra Bank (NRB), Economic Survey published by Ministry of Finance (MOF) and the World Economic Outlook by IMF. The GDP figures have been extracted from the World Economic Outlook database of IMF (available at http://econstats.com) which contains the time series data on the real GDP figures of Nepal calculated at the base year price of FY 2000/01 
adjusted to the base year price by data splicing chain weighted method. The information pertaining to the money balances and interest rates on saving and oneyear fixed deposit have been extracted from Quarterly Economic Bulletin (various issues). The data on the CPI (FY 2000/01=100) have been extracted from the Economic Survey 2009/10.

\section{Estimation Results}

First of all, it is necessary to confirm that none of the variables in the system are integrated of order more than one. If any variable is integrated of order two or more, ARDL modeling to cointegration cannot be used. With the ADF test, it has been confirmed that none variables are integrated of order higher than one. The results of ADF test have been provided in the appendix.

Following the ARDL Modeling to the formulation of money demand function as popularized by Pesaran and Shin (1997), the bounds test (F-statistics) has been applied to justify the existence of the cointegration or long-run relationship among variables in the system. Table (2) provides the results of the F-statistics according to various lag orders.

Table 2: F-statistics (Bound Test)

\begin{tabular}{llll}
\hline Lag order & & $\mathbf{0}$ & $\mathbf{1}$ \\
\hline F statistic & M1 Aggregate & 3.75 & $4.55^{*}$ \\
& M2 Aggregate & $7.65^{* *}$ & $4.94^{* *}$ \\
\hline
\end{tabular}

Note: The relevant critical value bounds are (with intercept and no trend; number of regressors $=2$ ) $3.79-4.85$ at the $95 \%$ significance level and $3.18-4.12$ at the $90 \%$ significance level; $*$ denotes that the F-statistic falls above the $90 \%$ upper bound and ** denotes above the $95 \%$ upper bound.

The results of Table (2) shows that most of the F-statistics are above the upper bounds of the Critical Values (CV) of standard significance levels (5\% or $10 \%$ ) provided by Pesaran and Pesaran (1997). But these critical values were generated on the basis of 40,000 replications of a stochastic simulation for a sample of 1,000 observations. So, they are less relevant for a small sample size. Therefore, following the critical values by Narayan and Smyth (2004) which are based on 40,000 replication of a stochastic simulation for a sample of 40 observations with two regressors, the critical value bounds are 2.83 to 3.58 at $10 \%$ and 3.43 to 4.26 for $5 \%$ level of significance. Based on these critical values, the calculated F-statistics clearly rejects null hypothesis of no cointegration at $5 \%$ or $10 \%$ level of significance. These values support the existence of cointegration or long-run relationship between variables in the equation. However, Bahmani-Oskooee and Rehman (2005) consider these results as preliminary, precisely due to arbitrary choice of lag selection, and rely more on the other stages of estimation for testing cointegration which are more efficient.

In the second step, equation (4) is estimated and different model selection criteria are used to justify the lag orders of each variable in the system. Only an appropriate lag selection criterion will be able to identify the true dynamics of the model. The maximum lag order is set to two, following Pesaran and Shin (1999) and Narayan and Smyth (2004) as the data are annual and there are only 35 
observations. With this maximum lag order, the adjusted sample period for analysis becomes 1977 to 2009 . This setting also helps save the degree of freedom, as our available sample period for analysis is quite small. Using Microfit 5.0, all the selection criteria have given the same results. Microfit runs the $(p+1)^{k}$ numbers of regressions and selects the best model on the basis of different model selection criteria, where $p$ is the maximum number of lags to be used and $k$ is the number of variables in the equation. Here, the number of regressions to be run are $(2+1)^{3}=$ 27 . The ARDL $(1,0,0)$ model is selected on the basis of all criteria like Adjusted $R^{2}$, Schwarz Bayesian Criterion (SBC), Akaike Information Criterion (AIC), and Haann Quinn criterion for both M1 aggregate and M2 aggregate models. According to Pesaran and Pesaran (1997), AIC and SBC perform relatively well in small samples, although the SBC is slightly superior to the AIC (Pesaran and Shin, 1999). Besides, $\mathrm{SBC}$ is parsimonious as it uses minimum acceptable lag while selecting the lag length and avoid unnecessary loss of degrees of freedom. Therefore, SBC criterion has been used, as a criterion for the optimal lag selection, in all cointegration estimations.

After selecting the appropriate lag orders for each variable in the system, equation (4) is re-estimated. The results of such estimation along with the short-run diagnostic statistics are presented in Table (3).

Table 3: Full-information ARDL Estimate Results (M1 monetary aggregate)

Autoregressive Distributed Lag Estimates

ARDL $(1,0,0)$ selected based on Schwarz Bayesian Criterion

Dependent variable is $\ln \mathrm{m}_{1 \mathrm{t}}$

33 observations used for estimation from 1977 to 2009

\begin{tabular}{|c|c|c|}
\hline Regressors & Coefficient & T-Ratio[Prob] \\
\hline$\Delta \ln m_{1 t}(-1)$ & $0.51 *$ & $4.45[0.00]$ \\
\hline$\Delta y_{t}$ & $0.67 *$ & $4.10[0.00]$ \\
\hline$\Delta r_{\text {sdt }}$ & -0.002 & $-0.26[0.79]$ \\
\hline C & $-5.26 *$ & $-3.99[0.00]$ \\
\hline $\begin{array}{l}\text { R-Squared } 0.99 \\
\text { S.E. of Regression } 0.04\end{array}$ & \multicolumn{2}{|c|}{$\begin{array}{l}\text { R-Bar-Squared } 0.99 \\
\text { F-Stat. } F(3,29) 1855.9[0.00]\end{array}$} \\
\hline \multicolumn{3}{|l|}{ Diagnostic Tests } \\
\hline Test Statistics & LM Version & F Version \\
\hline A:Serial Correlation & CHSQ(1) $=0.33[0.56]$ & $F(1,28)=0.28[0.59]$ \\
\hline B:Functional Form & CHSQ $(1)=3.87[0.04]$ & $F(1,28)=3.72[0.06]$ \\
\hline C:Normality & $\mathrm{CHSQ}(2)=1.20[0.54]$ & Not applicable \\
\hline D:Heteroscedasticity & $\mathrm{CHSQ}(1)=0.008[0.93]$ & $F(1,31)=.007[0.93]$ \\
\hline
\end{tabular}

Note: A: Lagrange multiplier test of residual serial correlation; B: Ramsey's RESET test using the square of the fitted values; C: Based on a test of skewness and kurtosis of residuals; D: Based on the regression of squared residuals on squared fitted values; *denotes the significance of coefficient at $5 \%$ level

Table (3) indicates that the overall goodness of fit of the estimated ARDL regression model is very high with the result of adjusted $R^{2}=0.99$. From the diagnostic tests, it is clear that the model passes all of the tests. The critical values of $\chi 2$ for one and two degrees of freedom at $5 \%$ level of significance are 3.84 and 5.99 
respectively. Thus, null hypothesis of normality of residuals, null hypothesis of no first order serial correlation and null hypothesis of no heteroscedasticity are accepted. However, the null hypothesis of no misspecification of functional form can be accepted at $10 \%$ level of significance only.

The estimated long-run model of the corresponding ARDL $(1,0,0)$ for the demand for narrow money balances is:

$\ln m_{1 t}=-10.89+1.39 \ln y_{t}-0.0039 r_{s d t}$

The long-run coefficients are the values of coefficients $\gamma_{1}$ to $\gamma_{3}$ of equation (4) normalized on $\ln \mathrm{m}_{1 \mathrm{t}}$ by dividing the coefficients by the coefficient $\left(-\gamma_{1}\right)$.

The long-run coefficients are reported in Table (4). As expected, the coefficient of the real income (GDP) is positive and that of short-term interest rate is negative. Quantitatively, the income elasticity of narrow money demand is 1.39, which is highly significant as reflected by a t-statistic of 27.40 . This in turn shows that one percentage increase in real GDP leads to increase in the real money balance holdings by 1.39 percentages. Thus, money seems to be a luxury asset in Nepal. This result is in conformity with many studies done in underdeveloped countries like Poudel (1989) and Khatiwada (1997) for Nepal, Aghevli et.al. (1979) and Teseng and Corker (1991) for Asian countries and Simmons (1992) for African Countries. It thus rejects the conclusion of Gaudel (2003) that income elasticity of demand for money is less than unitary in Nepal. The more than unity elasticity implies that an increase in income leads to a higher increase in the demand for real money balances and a reduction in the velocity of money (Rutayisire, 2010). This result is attributed to the under-monetization of the economy where the gradual absorption of the non-monetary sector by the monetary sector is accompanied by an increase in cash in hand that is faster than income.

Table 4: Estimated Long-run Coefficients using the ARDL Approach

ARDL $(1,0,0)$ selected based on Schwarz Bayesian Criterion

Dependent variable is $\ln \mathrm{m}_{1 \mathrm{t}}$

33 observations used for estimation from 1977 to 2009

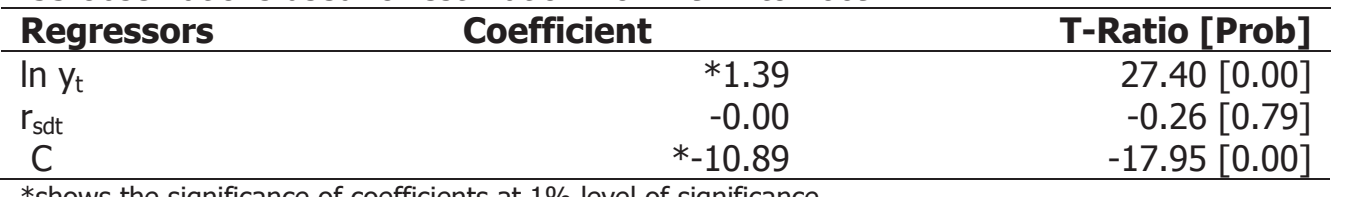

*shows the significance of coefficients at $1 \%$ level of significance

The interest rate despite bearing the correct negative sign is statistically insignificant which implies that in the long-run the demand for narrow money balances remains independent of the interest rate. Thus, either the interest rate is not a good proxy of the opportunity cost of holding money or interest rate does not have a significant effect on the demand for narrow money balances in Nepal. In an attempt to search for a suitable appropriate opportunity cost variable in the narrow money demand function, the interest rate on one-year fixed deposit was tried instead of interest rate on saving deposit but it also did not appear to be fruitful. 
Also, the real rates of interest were tried, but none of them carried significant tratio. Lastly, the inflation rate also did not turned out to be a significant opportunity cost variable in money demand function (Estimation Results are provided in the Annex). These results strongly support the view of Johnson (1963) that in less developed country, there is a possibility of keeping a block of cash by an individual out of his remuneration, investing the rest in assets and thereby reducing the interest elasticity of money demand to less than unity or even zero. The result that inflation also is not a significant opportunity cost of holding narrow money balances is in conformity with Pandey (1998) but in contradiction with several other studies done in developed countries. This result points to two possibilities: either the actual rate of inflation is not a good proxy of the expected rate of inflation or inflation does not have a significant impact upon the demand for real money balances in Nepal.

The estimates of the error correction representation of the ARDL $(1,0,0)$ model selected by the SBC criterion are presented in Table (5). The long-run coefficients are used to generate the error correction term, that is, ecm $=\ln m_{1 t}-1.39 \ln y_{t}+$ $0.0039 \mathrm{r}_{\text {sdt }}+10.89$. The computed F-statistic clearly rejects the null hypothesis that all regressors have zero coefficients. The JB test for normality shows that the residuals of the error correction modeling are normally distributed. The KB test supports the homoscedasticity assumption. Importantly, the error correction coefficient has the expected negative sign and is highly significant as shown by the probability value being zero. This helps to reinforce the existence of cointegration as provided by the F-test. Specifically, the estimated value of ecm $(-1)$ is -0.482 . The absolute value of the coefficient of $\mathrm{ecm}_{(-1)}$ is substantially high indicating the fast speed of adjustment to equilibrium following short-run shocks; about $48 \%$ of the disequilibrium, caused by previous period shocks, converges back to the longrun equilibrium in one period. The short-run coefficients show the dynamic adjustment of these variables. The coefficient of income and interest rate give the short- run elasticities of income and interest rate respectively. The short-run income elasticity thus is 0.67 which is less than the long-run elasticity 1.39 . On the other hand, as in the long-run, the short-run elasticity of interest rate is not statistically significant implying that demand for money even in the short-run remains independent of the interest rate. The adjusted R-square of the error correction model is rather low but it does not significantly affect our results since the variables are in the difference form [For example, see Omer (2010), Samreth (2008), Bahmani-Oskooee and Chi Wing $\mathrm{Ng}$ (2002)]. The low adjusted R-square is due to the selection of a restricted error correction model without a constant term following Pesaran and Shin (1999). 
Table 5: Error Correction Representation for the Selected ARDL Model ARDL $(1,0,0)$ selected based on Schwarz Bayesian Criterion Dependent variable is $\Delta \ln \mathrm{m}_{1 \mathrm{t}}$ 33 observations used for estimation from 1977 to 2009

\begin{tabular}{llll}
\hline Regressors & Coefficient & Standard Error & T-Ratio[Prob] \\
$\Delta \ln \mathrm{y}_{\mathrm{t}}$ & $0.67^{*}$ & 0.16 & $4.10[0.00]$ \\
$\Delta \mathrm{r}_{\mathrm{sdt}}$ & -0.0019 & 0.007 & $-0.26[0.79]$ \\
ecm $(-1)$ & $-0.48^{*}$ & 0.12 & $-4.14[0.00]$ \\
\hline
\end{tabular}

\section{R-Squared 0.37}

S.E. of Regression 0.04

JB(Normality) 1.20[0.54]

F-stat. (For KB heteroscedasticity test) : 0.09[0.75]

Note: R-Squared and R-Bar-Squared measures refer to the dependent variable $\Delta \mathrm{M}_{1 \mathrm{t}}$ and in cases where the error correction model is highly restricted, these measures could become negative; *shows the significance of coefficients at $1 \%$ level of significance.

Next, equation (4) is estimated for M2 monetary aggregates. Table (6) presents the estimated coefficients along with the diagnostic test statistics. The results are similar to the case of narrow money demand.

\section{Table 6: Full-information ARDL Estimate Results (M2 Monetary} Aggregate)

ARDL $(1,0,0)$ selected based on Schwarz Bayesian Criterion

Dependent variable is $\ln \mathrm{m}_{2 \mathrm{t}}$

33 observations used for estimation from 1977 to 2009

\begin{tabular}{llll}
\hline Regressors & Coefficient & Standard Error & T-Ratio[Prob] \\
$\Delta \ln \mathrm{m}_{2 \mathrm{t}}(-1)$ & $0.59^{*}$ & 0.08 & $6.82[0.00]$ \\
$\Delta \ln \mathrm{y}_{\mathrm{t}}$ & $0.72^{*}$ & 0.16 & $4.42[0.00]$ \\
$\Delta \mathrm{r}_{\mathrm{fdt}}$ & -0.00 & 0.004 & $-0.13[0.89]$ \\
$\mathrm{C}$ & $-5.70^{*}$ & 1.3 & $-4.26[0.00]$
\end{tabular}

Diagnostic Tests

Test Statistics

A:Serial Correlation

B:Functional Form

C:Normality

LM Version

$$
\text { CHSQ(1) }=0.06[0.79]
$$

$\mathrm{CHSQ}(1)=1.51[0.21]$

CHSQ(2) $=0.64[0.72]$

$\mathrm{CHSQ}(1)=0.003[0.95]$

Note: A:Lagrange multiplier test of residual serial correlation; B:Ramsey's RESET test using the square of the fitted values; C:Based on a test of skewness and kurtosis of residuals; D:Based on the regression of squared residuals on squared fitted values; *shows the significance of coefficients at $1 \%$ level of significance

From the diagnostic tests in Table (6), it is clear that null hypothesis of no first order serial correlation and null hypothesis of no heteroscedasticity and null hypothesis of no misspecification of functional form can be easily accepted at $5 \%$ level of significance. The estimated long-run money demand function for broad money aggregate is: 
$\ln m_{2 t}=-14.25+1.81 \ln y_{t}-0.0016 r_{f d t}$

The long-run coefficients are reported in Table (7).

Table 7: Estimated Long-run Coefficients using the ARDL Approach

ARDL $(1,0,0)$ selected based on Schwarz Bayesian Criterion

Dependent variable is $\ln \mathrm{m}_{2 \mathrm{t}}$

33 observations used for estimation from 1977 to 2009

\begin{tabular}{lrrr}
\hline Regressors & Coefficient & Standard Error & T-Ratio [Prob] \\
\hline $\ln y_{\mathrm{t}}$ & $1.81^{*}$ & 0.07 & $23.48[0.00]$ \\
$\mathrm{r}_{\text {fdt }}$ & -0.00 & 0.01 & $-0.13[0.89]$ \\
$\mathrm{C}$ & $-14.25^{*}$ & 0.90 & $-15.70[0.00]$ \\
\hline
\end{tabular}

Note: Figures in parentheses are the probabilities associated with the t-ratios and the asterisk * shows that the coefficient is significant at $1 \%$ level of significance.

As in the narrow money demand model, the coefficient of the real income (GDP) is positive and that of one year fixed deposit interest rate is negative. Quantitatively, the income elasticity of broad money demand is 1.81 , which is highly significant as reflected by a t-statistic of 23.48. This in turn shows that one percentage increase in real GDP leads to increase in the real money balance holdings by 1.81 percentages. It also implies that the income elasticity for broad definition of money is higher than narrow money. This result is again in conformity with Poudel (1989) and Khatiwada (1997) for Nepal. The interest rate despite bearing the correct negative sign is again statistically insignificant which implies that in the long-run, either, the demand for broad money balances remains independent of the interest rate or the chosen interest rate $r_{\text {fdt }}$ is not an appropriate opportunity cost variable. Here also, in search for an appropriate opportunity cost variable, the real rate of interest was tried but the coefficient of interest rate did not appear to be significant. This again is in conformity with the view of Johnson (1963). Finally, the rate of inflation also did not prove fruitful. As the intercept term is statistically significant, it implies that unidentified variables including time trend have significant bearings on real money demand and they have a negative impact on real money demand (Khatiwada, 1997).

The error correction representation for broad money aggregate model has been presented in Table (8), which reconfirms the cointegrating relationship between the variables included in the broad money demand function as revealed by the expected negative sign with the error correction term with a highly significant probability value of zero. The long-run coefficients are used to generate the error correction term, that is, ecm $=\ln \mathrm{m}_{2 t^{-}}{ }^{1.81}{ }^{*} \ln y_{t}+0.0016 * r_{\text {fdt }}+14.25 * \mathrm{C}$. The computed F-statistic clearly rejects the null hypothesis that all regressors have zero coefficients. Specifically, the estimated value of ecm $(-1)$ is -0.40 . The absolute value of the coefficient of ecm ${ }_{(-1)}$ is substantially high indicating the fast speed of adjustment to equilibrium following short-run shocks; about $40 \%$ of the disequilibrium, caused by previous period shocks, converges back to the long-run equilibrium in one period. Since, the absolute value of the coefficient of ecm is lower in case of broad money demand, there is a slower speed of adjustment of 
short-run disequilibrium to the long-run equilibrium in case of broad money demand function.

Table 8: Error Correction Representation for the Selected ARDL Model

$\operatorname{ARDL}(1,0,0)$ selected based on Schwarz Bayesian Criterion

Dependent variable is $\Delta \mathrm{ln} \mathrm{m}_{2 \mathrm{t}}$

33 observations used for estimation from 1977 to 2009

\begin{tabular}{lccc}
\hline Regressors & Coefficient & Standard Error & T-Ratio[Prob] \\
$\Delta \ln \mathrm{y}_{\mathrm{t}}$ & 0.72 & 0.16 & $4.42[0.00]$ \\
$\Delta \mathrm{r}_{\mathrm{fdt}}$ & -0.00 & 0.00 & $-0.13[0.89]$ \\
$\mathrm{ecm}(-1)$ & -0.40 & 0.08 & $-4.55[0.00]$ \\
\hline R-Squared & 0.41 & R-Bar-Squared & 0.35 \\
S.E. of Regression 0.03 & F-Stat. F $(3,29)$ & $6.98[0.00]$ \\
ecm $=$ In $\mathrm{m}_{2 \mathrm{t}}-1.81 * \ln \mathrm{y}_{\mathrm{t}}+0.0016{ }^{*} \mathrm{r}_{\mathrm{fdt}}+14.25^{*} \mathrm{C}$ & \\
JB(Normality) & $0.64[0.72]$ & \\
F-stat. (For KB heteroscedasticity test): $0.02[0.87]$ & \\
\hline
\end{tabular}

Note: R-Squared and R-Bar-Squared measures refer to the dependent variable $\Delta \mathrm{M}_{1}$ and in cases where the error correction model is highly restricted, these measures could become negative

The coefficient showing the short-run dynamics are not all significant: only the short-run income elasticity $(0.72)$ is significant where as the short-run interest rate elasticity is not significant though having a correct sign implying that money demand in the short-run also remains independent of the interest rate. All these coefficients show the dynamic adjustment of these variables.

\section{Stability Test}

Finally, the stability of the long-run coefficients together with the short-run dynamics is examined. In doing so, Pesaran and Pesaran (1997) have been followed and the CUSUM and CUSUMSQ tests [proposed by Brown, Durbin, and Evans (1975)] have been applied. The tests are applied to the residuals of the two models following Pesaran and Pesaran (1997). Specifically, the CUSUM test makes use of the cumulative sum of recursive residuals based on the first set of $n$ observations and is updated recursively and plotted against break points. If the plot of CUSUM statistics stays within the critical bounds of $5 \%$ significance level represented by a pair of straight lines drawn at the $5 \%$ level of significance whose equations are given in Brown, Durbin, and Evans (1975), the null hypothesis that all coefficients in the error correction model are stable cannot be rejected. If either of the lines is crossed, the null hypothesis of coefficient constancy can be rejected at the $5 \%$ level of significance. A similar procedure is used to carry out the CUSUMSQ test, which is based on the squared recursive residuals.

Figure (1) provides the plot of the cumulative sum of recursive residuals for narrow money demand model based on the SBC criterion. As the plot is within the $5 \%$ band shown by straight lines, no evidence of structural instability is present in case of narrow model demand. 
Figure 1: Plots of CUSUM Statistics (M1 Aggregate)

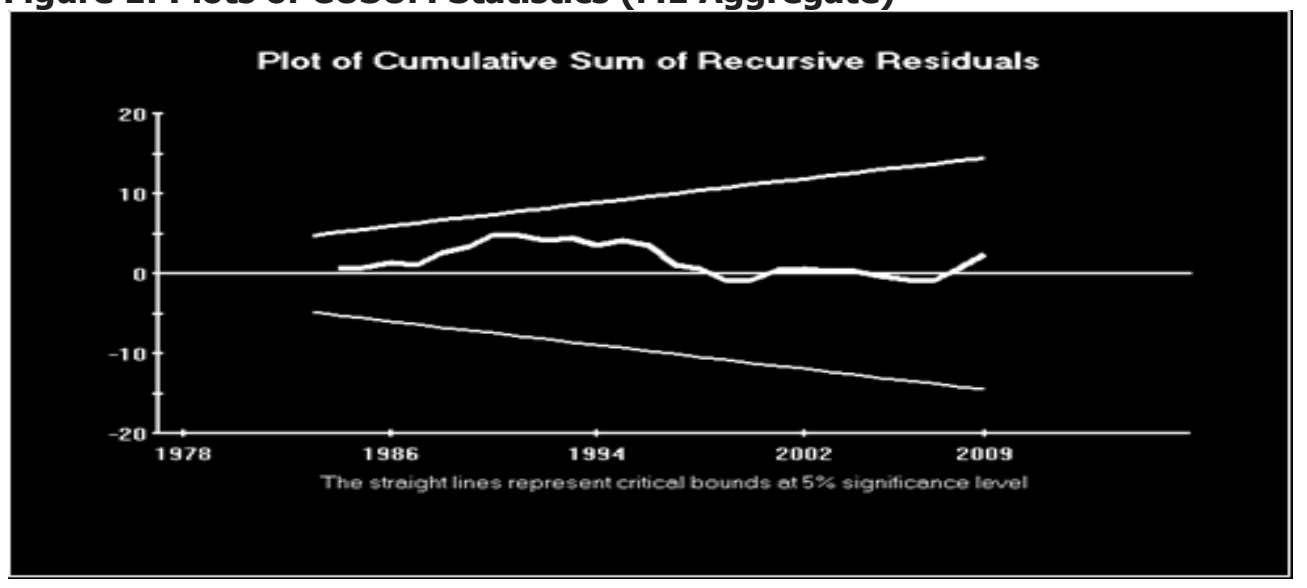

Figure (2) shows the plot of cumulative sum of squares of recursive residuals for narrow money demand model based on SBC criterion. Here also, the plot stays comfortably within the $5 \%$ band supporting the stability in case of narrow money demand.

\section{Figure 2: Plots of CUSUMQ Statistics (M1 Aggregate)}

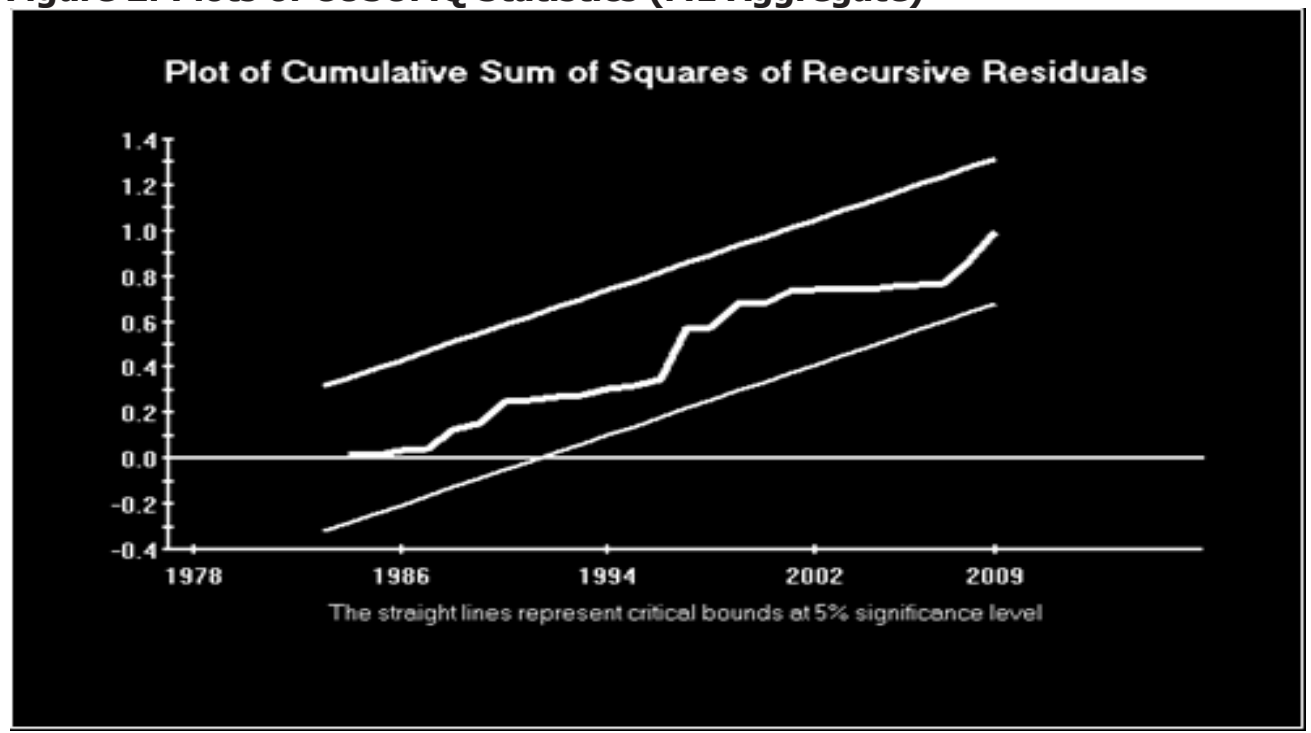

Figure (3) provides the plot of the cumulative sum of recursive residuals for broad money demand model based on the SBC criterion. As the plot does not cross the $5 \%$ band shown by straight lines, no evidence of structural instability is present in case of narrow model demand. 
Figure 3: Plots of CUSUM Statistics (M2 Aggregate)

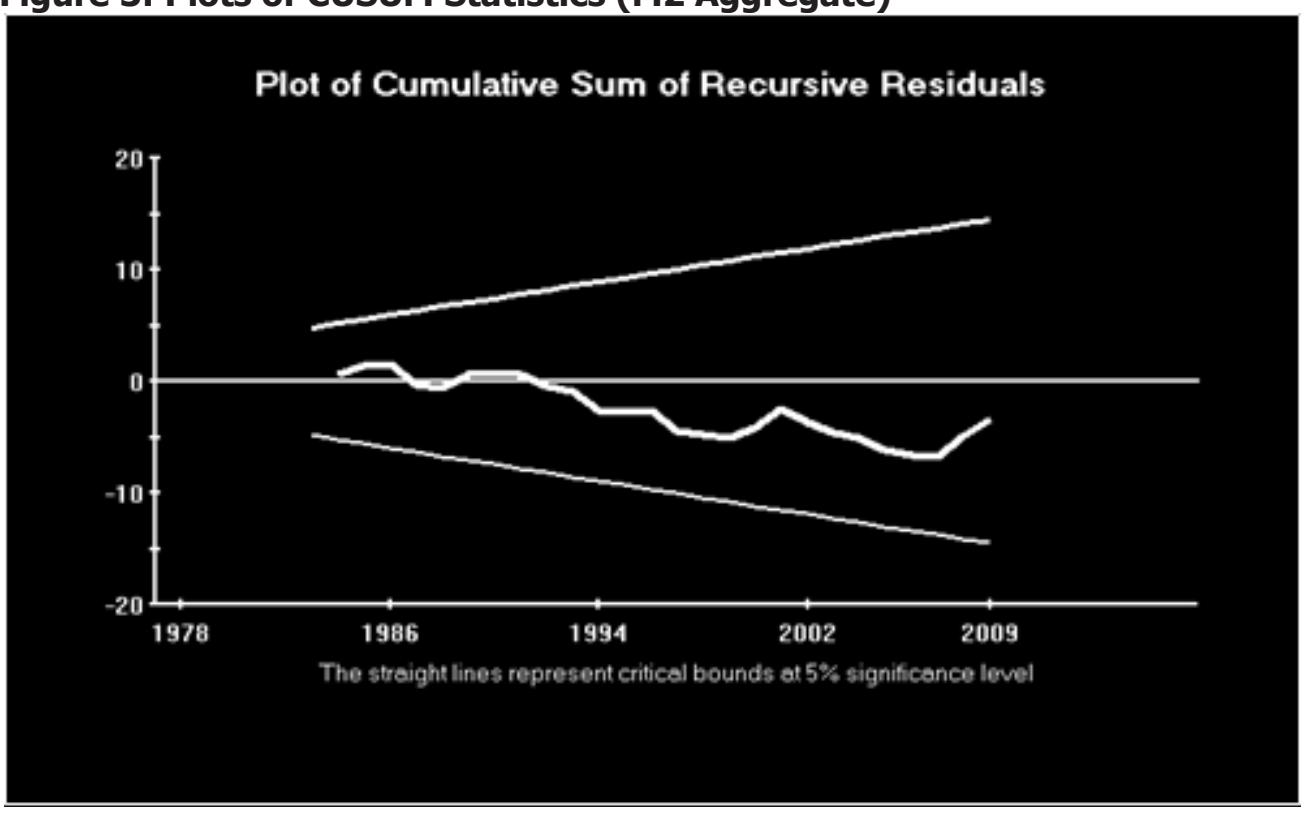

Figure (4) shows the plot of cumulative sum of squares of recursive residuals for broad money demand model. Here also, the plot stays comfortably within the $5 \%$ band supporting the stability in case of broad money demand.

\section{Figure 4: Plots of CUSUMSQ Statistics (M2 Aggregate)}

\section{Plot of Cumulative Sum of Squares of Recursive Residuals}

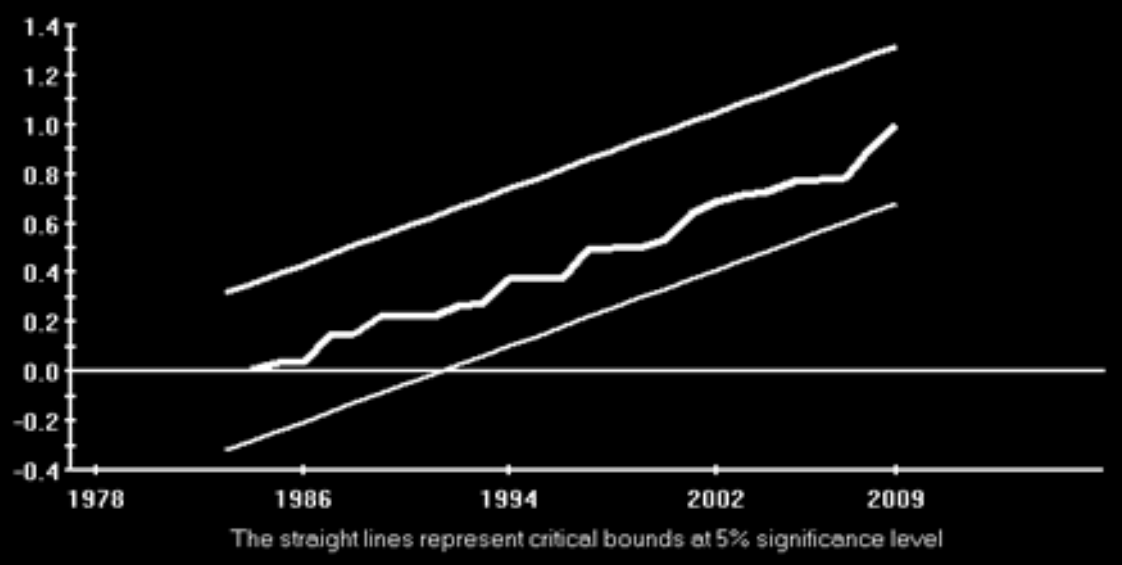

Based on these evidences, it is safe to conclude that the estimated demand functions for narrow and broad money balances are stable. 


\section{CONCLUSIONS}

The main purpose of this paper is to examine the long-run cointegrating relationship among the demand for real money balances and its determinants and to examine the long-run stability issue of the demand for money holdings. It has used the ARDL modeling to cointegration analysis proposed by Pesaran and Shin (1999). The results show that there is a long-run equilibrium relationship among the demand for real balances and its determinants in case of both narrow and broad money aggregates. Further, the CUSUM and CUSUMSQ test have confirmed the stability of the long-run money demand functions. The stability of money demand function implies that the central bank of Nepal can rely on the monetary aggregates as intermediate targets in the formulation of monetary policy of Nepal.

\section{ACKNOWLEDGEMENT}

This research has received the 'Mahesh Chandra Manoregmi Prize' of 2069 and the author wants to thank Associate Prof. Anant K. Mainali and the Governor of Nepal Rastra Bank Dr. Yuba Raj Khatiwada for the supervision of this research. The author also wants to acknowledge the help by Mr. Naveen Adhikari and Mr. Birendra Budha for their comments to improve this article.

\section{REFERENCES}

Achsani, N.A. 2010. Stability of Money Demand in an Emerging Market Economy: An Error Correction and ARDL Model for Indonesia. Research Journal of International Studies 13.

Aghevli, B.B., M.S. Khan, P.R. Narvekar, and B.K. Short. 1979. Monetary Policy in Selected Asian Countries. IMF Staff Papers 26: pp. 775-824.

Ahmed, S. and Md. Ezazul Islam. 2007. A Cointegrating Analysis of the Demand for Money in Bangladesh. Working Paper Series, Research Division, Bangladesh Bank.

Akinlo, A.E. 2006. The Stability of Money Demand in Nigeria: An Autoregressive Distributed Lag Approach. Journal of Policy Modeling 28: pp. 445-452.

Arango, S. and M.I. Nadiri .1981. Demand for Money in Open Economies. Journal of Monetary Economics 7: pp. 69-83.

Bahmani-Oskooee, M. 2001. How Stable is M2 Money Demand Function in Japan? Japan and the World Economy 13: pp. 455-461.

Bahmani-Oskooee, M. and H. Rehman. 2005. Stability of Money Demand Function in Asian Developing Countries. Applied Economics 37: pp. 773-792.

Bahmani-Oskooee, M. and Sahar Bahmani. 2007. Exchange Rate Volatility and Demand for Money in Iran? An Unpublished Paper, Department of Economics, The University of Wisconsin-Milwaukee, Milwaukee, Wisconsin 53201.

Bahmani-Oskooee, M. and Raymond Chi Wing Ng. 2002. Long-run Demand for money in Hongkong: An Application of the ARDL Model. International Journal of Business and Economics 1(2): pp. 147-155.

Bahmani-Oskooee, M. and Yongqing Wang. 2007. How Stable is the Demand for Money in China? Journal of Economic Development 32(1). 
Banerjee, A., J. Dolado, J.W. Galbraith and D.F. Hendry. 1993. Co-integration, Error Correction and the Econometric Analysis of Non-stationary Data. Oxford: Oxford University Press.

Bhattacharya, B. B. 1974. Demand and Supply of Money in a Developing Economy: A Structural Analysis for India. The Review of Economics and Statistics 56(4): pp. 502-510.

Bose, S. and H. Rahman. 1996. Demand for Money in Canada: A Cointegration Analysis. International Economic Journal 10(4).

Boughton, J. M. 1981. Recent Instability of the Demand for Money: An International Perspective. Southern Economic Journal 47: pp. 579-597.

Brown, R., J. Durbin, and J. Evans. 1975. Techniques for Testing the Constancy of Regression Relations Over Time. Journal of the Royal Statistical Society, Series B, 37: pp. 149-63.

Brunner K. and A.H. Meltzer. 1964. Some Further Evidence on the Supply and Demand Functions for Money. Journal of Finance 19, May, 1964.

Butter, F.A.G. Den, and M.M.G. Fase. 1981. The Demand for Money in EEC Countries. Journal of Monetary Economics 8 : pp. 201-230.

Cameron N. 1979. The Stability of Canadian Demand for Money Function 1954-75. The Canadian Journal of Economics, vol. 12, no. 2 : pp. 258-281.

Chow, G.C. 1966. On the Long-run and Short-run Demand for Money. Journal of Political Economy. April: pp. 111-131.

Cooley, T. F. and E. C. Prescott. 1973. Systematic Variation Models Varying Parameter Regression: A Theory and Some Applications. Annals of Economic and Social Measurement, 2(4) : pp. 463-473.

Engle, Robert F. and C. W. J. Granger. 1987. Cointegration and Error Correction Representation, Estimation, and Testing, Econometrica. 55 : pp. 251-276.

Gaudel, Y.S. 2003. Monetary System of Nepal. New Delhi: Adroit Publishers.

Goldfeld, S.M. 1973. The Demand for Money Revisited, Brookings Papers on Economic Activity, 3: pp. 577-646.

Granger, C.W.J. 1981. Some Properties of Time Series Data and Their Use in Econometric Model Specification. Journal of Econometrics 16: 121-130.

Gujarati, D. 1978. The Demand for Money in India. Journal of Development Studies 5(1): pp. 59-64

Gupta, K.L. 1970. The demand for Money in India: Further Evidence. Journal of Development studies 6 : pp. 159-168.

Halicioglu, F. and Mehmet Ugur. 2005. On Stability of Money Demand for a Devoloping OECD Country. Global Business and Economic Review 7(8).

Hamburger, M.J. 1966. The Demand for Money by Households, Money Substitutes, and Monetary Policy. Journal of Political Economy 74: pp. 600-623.

Hamori, N. and S. Hamori. 1999. Stability of Money Demand Function in Germany. Applied Economics Letters, 6: pp. 329-332.

Heller, H.R. 1965. The Demand for Money: The Evidence from the Short-run Data. Quarterly Journal of Economics 79 (June 1965): pp. 291-303.

Jacobs, R.L. 1974. Estimating the Long-Run Demand for Money from Time Series Data. Journal of political Economy 82(6): pp. 1221-1238.

Johansen, S. 1988. Statistical Analysis of Cointegration Vectors. Journal of Economic Dynamics and Control, 12(2/3): pp. 231-254. 
Johansen, S. and Juselius, K. 1990. Maximum Likelihood Estimation and Inference on Cointegration: With Applications to the Demand for Money. Oxford Bulletin of Economics and Statistics 52(2): pp. 169-210.

Johnson, H.J. 1963. Notes on the Theory of Transaction Demand for Cash. Indian Journal of Economics. 44(172): pp. 1-11.

Khan, M.A. and Md Abdul Wadud. 2003. Monetary Mechanism in Bangladesh: A Cointegration and Error Correction Modeling Appraoch. A Paper presented at the 2nd European Integration and Banking Efficiency Workshop held on October 30-31, 2003 at Lisbon, Portugal.

Khan, M.S. 1974. The Stability of the Demand for Money Functions in the United States, 1901-1965. Journal of Political Economy 82(6): pp. 1205-1220.

Khatiwada, Y.R. 1997. Estimating the Money Demand in Nepal: Some Empirical Issues. Economic Review, Occasional Papers. NRB No. 9.

Laidler, D.E.W. 1966. Some Evidence on the Demand for Money. Journal of Political Economy 74(1) : pp. 55-61.

Laidler, D.E.W. 1971. The Influence of Money on Economic Activity: A Survey of Some Current Problems. Monetary Theory and Monetary Policy in the 1970s (Proceedings of the 1970 Shetfield Money Seminar ), Oxford University Press.

Laurenceson, J. and J.C.H. Chai. 2003. Financial Reform and Economic Development in China. Cheltenham.

Lumas, G.S. and Y.P. Mehra. 1976. The Stability of the Demand for Money Function: The Evidence from Quarterly Data. The Review of Economics and Statistics 58(4): pp. 463-468.

Mehra, Y.P. 1991. An Error-Correction Model of U.S. M2 Demand. Federal Reserve Bank of Richmond Economic Review 77(May/June): pp. 3-12.

Meltzer, A.G. 1963. Demand for Money: Evidence from the Time series. Journal of Political Economy : pp. 219-246.

Narayan, P.K. and Russel Smyth. 2004. Temporal Causality and the Dynamics of Exports, Human Capital and Real Income in China. International Journal of Applied Economics 1: pp. 24-35.

Omer, M. 2010. Stability of Money Demand Function in Pakistan. SPB Working Paper Series, 36(Aug).

Pandey, R.P. 1998. An Application of Cointegration and Error Correction Modeling: Towards Demand for Money in Nepal. Economic Review, Occasional Papers. NRB No.10.

Pesaran and B. Pesaran. 1997. Working with Microfit 4.0: Interactive Econometric Analysis. Oxford University Press.

Pesaran and Y. Shin. 1999. An Autoregressive Distributed Lag Modeling Approach to Cointegration Analysis. Econometrics and Economic Theory in the 20th Century, The Ragnar Frisch Centennial Symposium, 1998, Cambridge University press, Cambridge.

Pesaran, M. H., Y. Shin, and R. J. Smith. 1996. Bounds Testing Approaches to the Analysis of Level Relationships. DEA Working Paper 9622, Department of Applied Economics, University of Cambridge.

Pesaran, M. H., Y. Shin, and R. J. Smith. 2001. Bounds Testing Approaches to the Analysis of Level Relationships. Journal of Applied Econometrics 16: pp. 289-326. 
Poudyal, S.R. 1989. The Demand for Money in Nepal. Economic Review, Occasional Papers, NRB No.3.

Rutaysire, M. J. 2010. Economic Liberalization, Monetary Policy and Demand for Money in Rwanda: 1980-2005. AERC Research Paper 193, African Research Consortium, Nairobi, January 2010.

Sampath, R.K. and Zakir Hussain (1981). Demand for Money in India. The Indian Economic Journal, 29(1): pp. 17-36.

Samreth, S. 2008. Estimating the Money Demand Function in Combodia: ARDL Approach. MRPA Paper No.16274, posted on July 2009.

Simmons, R. 1992. An Error-correction Approach to Demand for Money in Five African Developing Countries. Journal of Economic Studies, 19: 29-47.

Sriram, S.S. 2000. A Survey of Recent Empirical Money Demand Studies. IMF Staff Paper 47(3): pp. 334-365.

Taylor, M.P. 1993. Modeling the Demand for UK Broad Money. The Review of Econimics and Statistics 75 (1) : pp. 112-117.

Tseng, W. and R. Corker. 1991. Financial Liberalization, Money Demand, and Monetary Policy in Asian Countries. IMF Occasional Paper No. 84, International Monetary Fund, Washington, D.C. 


\section{APPENDIX}

Table A1: ADF Test Results $(p=1)$

\begin{tabular}{|c|c|c|}
\hline Variables & Constant & Constant and trend \\
\hline $\ln m_{1 t}$ & -0.38 & -4.25 \\
\hline $\ln m_{2 t}$ & -0.60 & -5.04 \\
\hline $\ln y_{t}$ & -0.98 & -2.99 \\
\hline$r_{\text {sdt }}$ & -1.48 & -1.96 \\
\hline$r_{f d t}$ & -1.80 & -2.50 \\
\hline $\mathrm{rr}_{\mathrm{sdt}}$ & -4.60 & -4.58 \\
\hline $\mathrm{rr}_{\mathrm{fdt}}$ & -4.38 & -4.66 \\
\hline INF & -3.51 & -3.90 \\
\hline$\Delta \ln m_{1 t}$ & $-4.65 *$ & -4.42 \\
\hline$\Delta \ln m_{2 t}$ & $-5.65^{*}$ & -5.27 \\
\hline$\Delta \ln y_{t}$ & $-4.95^{*}$ & -5.20 \\
\hline$\Delta \mathrm{r}_{\mathrm{sdt}}$ & $-4.06 *$ & -3.93 \\
\hline$\Delta \mathrm{r}_{\mathrm{fdt}}$ & $-3.79 *$ & -3.70 \\
\hline$\Delta \mathrm{rr}_{\mathrm{sdt}}$ & $-6.93 *$ & -6.73 \\
\hline$\Delta \mathrm{rr}_{\mathrm{fdt}}$ & $-7.12 *$ & -6.92 \\
\hline$\Delta \mathrm{INF}$ & $-6.46 *$ & -6.25 \\
\hline
\end{tabular}

Table A2: Estimated Long-run Coefficients using the ARDL Approach ARDL $(1,0,0)$ selected based on Schwarz Bayesian Criterion

Dependent variable is $\ln \mathrm{m}_{1 \mathrm{t}}$

33 observations used for estimation from 1977 to 2009

\begin{tabular}{lrrr}
\hline Regressors & Coefficient & Standard Error & T-Ratio [Prob] \\
\hline $\ln y_{\mathrm{t}}$ & 1.36 & 0.07 & $18.09[0.00]$ \\
$\mathrm{r}_{\mathrm{fdt}}$ & -0.00 & 0.01 & $-0.71[0.48]$ \\
$\mathrm{C}$ & -10.45 & 0.88 & $-11.82[0.00]$ \\
\hline
\end{tabular}

Table A3: Estimated Long-run Coefficients using the ARDL Approach ARDL $(1,0,0)$ selected based on Schwarz Bayesian Criterion

Dependent variable is $\ln \mathrm{m}_{1 \mathrm{t}}$

32 observations used for estimation from 1978 to 2009

\begin{tabular}{lrrr}
\hline Regressors & Coefficient & Standard Error & T-Ratio [Prob] \\
\hline $\ln \mathrm{y}_{\mathrm{t}}$ & 1.42 & 0.07 & $19.96[0.00]$ \\
$\mathrm{rr}_{\text {sdt }}$ & 0.02 & 0.01 & $1.14[0.26]$ \\
$\mathrm{C}$ & -11.10 & 0.70 & $-15.67[0.00]$ \\
\hline
\end{tabular}

$t r_{\text {sdt }}$ is calculated as $r_{\text {sdt }}$ minus inflation 
Table A4: Estimated Long-run Coefficients using the ARDL Approach ARDL $(1,0,2)$ selected based on Schwarz Bayesian Criterion

Dependent variable is $\ln \mathrm{m}_{2 \mathrm{t}}$

32 observations used for estimation from 1978 to 2009

\begin{tabular}{lrrr}
\hline Regressors & Coefficient & Standard Error & T-Ratio [Prob] \\
\hline $\ln y_{\mathrm{t}}$ & 1.80 & 0.05 & $33.84[0.00]$ \\
$\mathrm{rr}_{\text {fdt }}{ }^{\dagger}$ & -0.00 & 0.00 & $-0.70[0.48]$ \\
$\mathrm{C}$ & -14.05 & 0.56 & $-24.84[0.00]$ \\
\hline
\end{tabular}

$\operatorname{trr}_{\text {fdt }}$ is calculated as $r_{\text {fdt }}$ minus inflation

Table A5: Estimated Long-run Coefficients using the ARDL Approach ARDL $(1,0,0)$ selected based on Schwarz Bayesian Criterion

Dependent variable is $\ln \mathrm{m}_{1 \mathrm{t}}$

32 observations used for estimation from 1978 to 2009

\begin{tabular}{lrrr}
\hline Regressors & Coefficient & Standard error & T-Ratio [Prob] \\
\hline In $y_{\mathrm{t}}$ & 1.39 & 0.06 & $21.92[0.00]$ \\
INF & -0.01 & 0.00 & $-1.15[0.25]$ \\
C & -10.78 & 0.68 & $-15.66[0.00]$ \\
\hline
\end{tabular}

Table A6: Estimated Long-run Coefficients using the ARDL Approach ARDL $(1,0,2)$ selected based on Schwarz Bayesian Criterion

Dependent variable is $\ln \mathrm{m}_{2 \mathrm{t}}$

32 observations used for estimation from 1978 to 2009

\begin{tabular}{lrrr}
\hline Regressors & Coefficient & Standard error & T-Ratio [Prob] \\
\hline In $y_{t}$ & 1.83 & 0.06 & $29.67[0.00]$ \\
INF & 0.00 & 0.00 & $0.53[0.59]$ \\
C & -14.42 & 0.66 & $-21.89[0.00]$ \\
\hline
\end{tabular}

